\title{
Economic net return analysis of Boswellia. Papyrifera (Del.) Hochst in the Blue Nile state, Sudan
}

\begin{abstract}
Boswellia. papyrifera (Del.) Hochst or frankincense tree is an important resource in the dry lands of the Blue Nile State. It is a multipurpose tree species with various environmental, cultural and socio-economic values. The objectives of the study were to analysis the socio-economic characteristics of workers and merchants and to conduct a net return analysis of frankincense yield for both of them. Primary data was collected using semistructured questionnaire during the season 2011/2012. A formal survey was conducted in five localities Kurmok, Damazin, Roseris, Gessan and Baw, where workers and merchants were randomly selected. The information included socio-economic characteristics of workers and merchants, production cost, output prices, production, total return, marketing of product and production constraints. The data analyzed using descriptive statistics. The study revealed that the mean age of workers were 40 years and 48 years for merchants, $51 \%$ and $95 \%$ of workers and merchants were married, The educational level range between 3 and $5 \%$ for secondary school, 36 and $95 \%$ for basic school for workers and merchant respectively .more than $90 \%$ of workers and merchant came from eastern Sudan. The average production cost per metric tons was 1668 SDG and local market price of metric tons was $4000 \mathrm{SDG}$, however the net return of frankincense was found to be 2332 SDG per metric tons. The study revealed that the main constraints hampering production are government fees, marketing, water and security.
\end{abstract}

Keywords: Boswellia papyrifera frankincense, net return, metric tons, questionnaire, socio economic
Volume 2 Issue 5 - 2018

\author{
Mahassin Mohammed Ahmed Abdalla,' \\ Ammar Fadlalla Gessmalla ${ }^{2}$ \\ 'Agricultural Economics and Policy Research Center, \\ Agricultural Research Corporation, Ministry of Agriculture and \\ Irrigation, Sudan \\ ${ }^{2}$ Forestry Research Centre, Damazin Research Station, \\ Agricultural Research Corporation (ARC), Sudan
}

Correspondence: Ammar Fadlalla Gessmalla, Forestry Research Centre, Damazin Research Station, Agricultural Research Corporation (ARC), Sudan, Email anfad4@yahoo.com

Received: November 13,2017| Published: October 31, 2018

\section{Introduction}

Many people in Sudan and around the world depend on trees to meet their basic needs for food, shelter, and non timber forest products, yet the environmental, cultural, social and economic values of trees are overlooked in development planning, land management and in international co-operation. Trees and forests contribute to the wide range needs of our changing society; they offer a key option to sustainable agriculture and economic growth in a world confronted by urgent demands of grows population. ${ }^{1}$ Boswellia papyrifera (Del.) Hochst is a deciduous dry-land tree species which belongs to the family Burseraceae. The family is distinguished by the presence of resin ducts in the bark and production of aromatic oils and resins. It is geographically distributed in drier parts of Africa from Nigeria in the west to Eritrea and Ethiopia in the East, being dominant in Ethiopia, Eritrea and Somalia. ${ }^{2}$ It is a multipurpose tree species with diverse socioeconomic and ecological importance. Almost all parts of the tree are used for different purposes. Its wood is used for pole and timber locally. It is the source of frankincense (gum olibanum) tapped for cash income and local uses. The leaves and seeds of $B$. papyrifera are highly valued as dry season fodder for goats, camels and other livestock. ${ }^{3,4}$ The sweet smelling flowers, that appears when the tree fell its leaves, are important sources of nectar for honey bees. Vollesn et al..$^{5}$ found Boswellia papyrifera in Ethiopia, Chad, Eritrea, Cameron, Central Africa Republic, Sudan and Uganda).

In Sudan Boswellia papyrifera trees grows and covers large areas in different parts south altitude $14^{\circ} \mathrm{N}$ and this includes the States of Blue Nile, Southern Kordofan, Western and Southern Dar Fur $^{1}$ its common savanna tree species as a pure stand or mixed with other species like Sterculia setigera, Combretum spp.,Terminalia and Commiphora species on slopes and land hills, the survival of the species in such marginal areas makes it a key stone species that can provide plant cover and protect the soil and provide shade. It also plays an important role in desertification control since it acts as defense line against desert creeping southwards. ${ }^{3,6}$ The area well stocked with species in Blue Nile State is approximately 130280 ha of which only 4880 ha are reserved forests, ${ }^{7}$ in the Blue Nile State the only species which belong to the genus is Boswellia papyrifera, occurs in Jebel El Garri, Ingasana hills and along the Sudan borders with Ethiopia. it's a deciduous tree up to $10 \mathrm{~m}$ high with pale yellowbrown papery bark, peeling off in wide strips, slash reddish exuding a fragrant resin, leaves $30 \mathrm{~cm}$ long. Flowers are pink clustered and short cushion like side branches, fruits are ovoid $1.85 \mathrm{~cm}$ long and beaked. ${ }^{8}$ The typical sites for $B$. Papyrifera are the hilly areas with shallow soils of low fertility. ${ }^{9}$ The species appears to be able to adapt to these harsh conditions. In neighboring countries it was found in similar growth habitats. ${ }^{9}$

Frankincense is an ancient product from Boswellia Papyrifera tree dated back to more than 4000 years. Nowadays it remains an important item of commerce in the international market. It is traditionally used as incense in religious or social ceremonies. ${ }^{4}$

\section{Uses of frankincense resin}

Frankincense and Myrrh products has wide- ranges of other industrial uses in the food industry as beverages, candles, chewing gums, confectioneries, gelatins, nut product, pudding and canned vegetables. Typical applications include: adhesive thickeners, thickeners, stabilizers, flavoring, fixatives, and emulsifying agents for rubber products. ${ }^{10}$

Several folklore claims about natural drugs have continued to be verified on modern scientific grounds. For instance, both frankincense 
and Myrrh have found modern pharmacological applications for several disease treatments most of them as predicted by the traditional therapies. Particularly, their unique chemical compositions, pharmacological activities and non- toxicity tend to support the safe use of these popular traditional drugs in modern therapies. ${ }^{11}$ The wood of Boswellia is used for poles and timber and industrial manufacturing of matchboxes, boards and plywood. The leaves provide dry-season fodder, and the flowers are good sources of nectar for bees. Leaves bark and roots are also used in traditional medicines. The species is recommended for economic development, water shed protection and desertification control. ${ }^{12}$ Ecologically the B. papyrifrea is important since it grows in areas where other trees fail to grow.

McMahon et al. ${ }^{13}$ outlined some of the uses of B. papyrifrea resin

1) Fresh gum is chewed for strengthening the teeth and stimulating digestion.

2) Distilled and extracted to yield essential oils and a costly perfume prepared using these aromatic oils.

3) Dissolved in milk and taken of cough.

4) Social and religious uses, where the resin is burned in weddings and religious occasions. It is said to keep away all evil influences.

5) A talcum powder is prepared using frankincense and ammonium salts to perfume and soften the skin.

Despite the economic and ecological benefits of the species to the local communities, governments, and the entire sub-regions in general, very little concern has been undertaken to develop the resource. Lack of reliable information is one of the major constraints that are hampering the efficient and economical development and use. ${ }^{14}$ Khamis ${ }^{15}$ Pointed that significant changes have taken place in the Boswellia papyrifera stands, due to the negative impacts of the current mode of utilization by the different stakeholders and the natural factors such as improper tapping, uncontrolled grazing, illicit felling, agricultural encroachment, fires, drought, winds and diseases with a consequent deterioration of these stands.

Blue Nile State is located in the south-eastern part of the Sudan, between Lat. $9^{\circ} 30^{\prime}$ to $12^{\circ} 30^{\prime} \mathrm{N}$, and Long. $33^{\circ} 5^{\prime}$ to $35^{\circ} 3^{\prime} \mathrm{E}$. The total area is about 38500 square $\mathrm{km}$. It is characterized by mountain series of which Ingassanaas is the main geographical feature which extends about $72 \mathrm{~km} .{ }^{16}$ The objectives of this study are to analysis the socioeconomic characteristics of workers and merchants and to conduct a net return analysis of frankincense yield for both of them. Table 1 showed the export quantities and average price of Frankincense in Sudan from 2004 to 2011. Quantities and prices showed great variations from year to year.

Table I Quantities and prices of Sudan exports of Frankincense from period 2004- 20II

\begin{tabular}{lll}
\hline Year & Quantity (ton) & Average price (US\$/ton) \\
\hline 2004 & 375.4 & 908 \\
2005 & 358 & 2028 \\
2006 & 183 & 788.5 \\
2007 & 76.4 & 746 \\
2008 & 20 & 1850 \\
2009 & NA & NA \\
\hline
\end{tabular}

Table Continued...

\begin{tabular}{lll}
\hline Year & Quantity (ton) & Average price (US\$/ton) \\
\hline 2010 & 3 & 766.7 \\
2011 & 1794 & 1158.6 \\
\hline
\end{tabular}

Source: Sudan Customs Police, Division of Export, 2012.

NA is not available.

\section{Material and methods}

Both primary and secondary data were used to satisfy the objectives of the study. Primary data was collected using semistructured questionnaire during the season 2011/2012. A sample of 70 workers and 20 merchants were randomly selected from five localities Kurmok, Damazin, Roseris, Gessan and Baw, number of workers were; $14,16,15,12$ and 13 workers from five localities respectively, while number of merchants were; 3, 7, 4, 2 and 4 merchants from five localities respectively. The collected information included socioeconomic characteristics of workers and merchants, production cost, prices product, total return, marketing of product and production constraints. The secondary data was collected from relevant literatures, scientific publications, Sudan Customs Police ${ }^{17}$ and internet. The data have been analyzed using descriptive techniques such as frequencies and percentages; this has been done through statistical package for social science (SPSS).

\section{Results and discussion}

\section{The system of frankincense collection}

Frankincense is mainly collected by merchants. Merchants usually hire groups of labors; each group (locally called 'tayeh') consists of 5 members. Frankincense represents a main source of income for respondent in the study area. Collection of Frankincense was the main occupation for all workers and merchants. $90 \%$ of the workers plant other crops such as Sorghum bicolor and Sesamum indicum in the area during the rainfall season. Figure 1 shows the structure of production relationship between merchants and labors in frankincense production in Blue Nile State season 2011. The merchants provide production costs and workers' needs such as transport, food, shelters, water, tools of tapping and collection, rent of store, cost of loading, payment of government fees and empty sacks. Tapping of frankincense usually begins in mid of September until end of October and collections start after 40- 45 days from tapping and continuo up to the end of the dry season, usually June and generally there are about 4-9 pickings per season depends on the weather conditions. At the end of the season the production is divided between workers and merchant equally, and then merchants deduct the cost of production from workers share except the cost of water, tools of both tapping and collection. This method of product sharing encourages workers to collect more Frankincense because they are poor and do not have the ability to work on their own.

Main constraints facing the workers and merchants are high government fees, food, access to water (there are no sources of water in production area, and merchants have to transfer water from near villages to production areas), finance (merchants depend on self finance), marketing (workers sell their production to merchants, local merchants deport their production to Khartoum ${ }^{18}$ and sell it to exporters). Security also poses a serious problem facing producers; there are conflicts between groups in production area. 


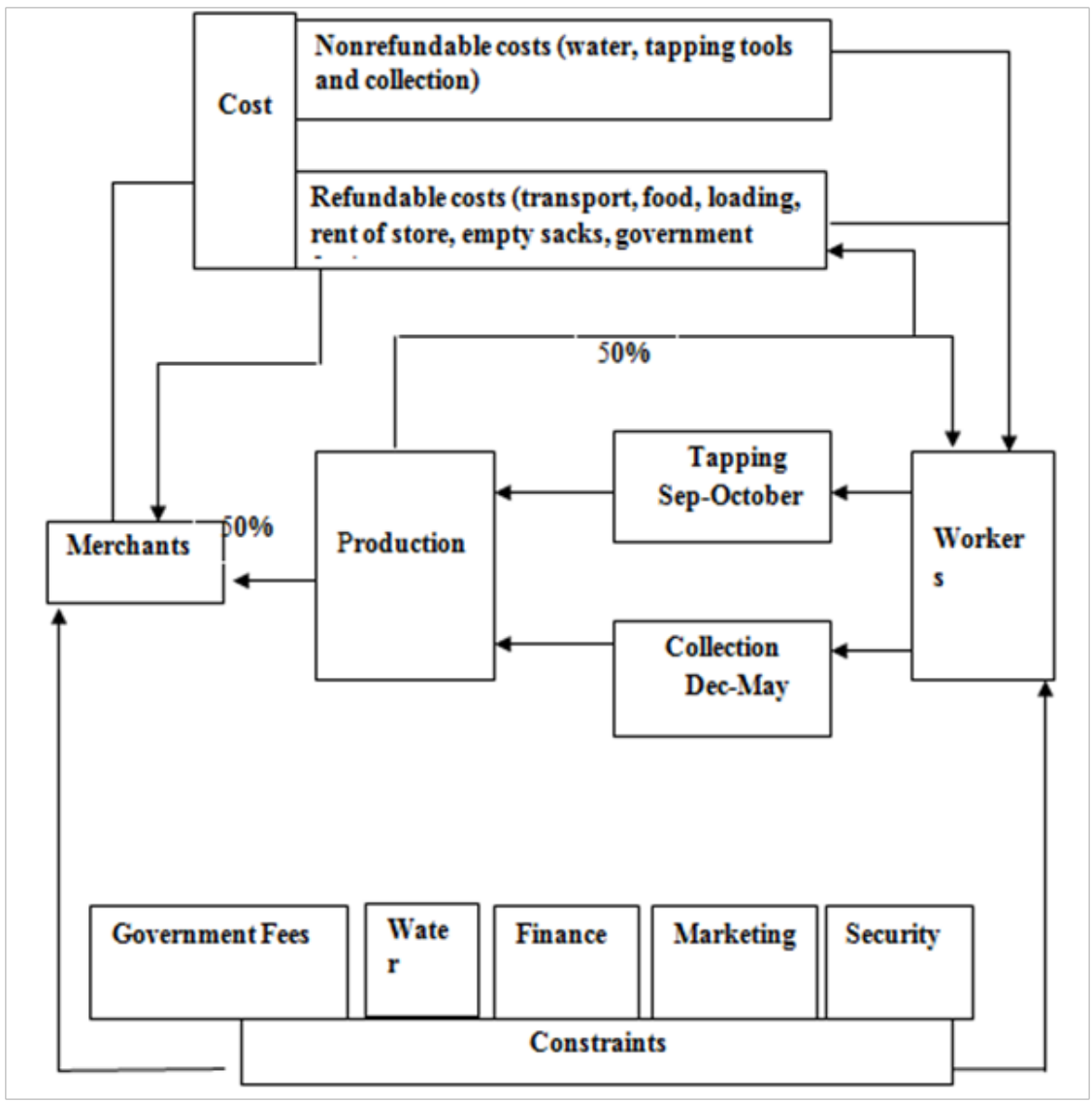

Figure I Relationship between merchants and workers in frankincense production, in Blue Nile State and main constrain.

\section{Socioeconomic characteristics of sample workers}

Table 2 shows workers are exclusively males with average age of about 40 years, $53 \%$ of the sampled workers were young below 40 years, while $43 \%$ of them were from $41-50$ years, this result indicates that the workers is in the productivity age, and this will support the production and protection of the frankincense, most of them, 93\%, came from Eastern Sudan ,they were belonging to Bni Amir tribe who migrate from Eastern Sudan to look for work, some of workers settled in the Blue Nile State and others were moving between Blue Nile State and Western Sudan depending on harvesting season. About $51 \%$ of them were married while $46 \%$ were unmarried, $61 \%$ of the sampled workers were illiterate and $36 \%$ of them attained basic school, this may be the reason of their dependency on handcrafts, $48 \%$ of workers had experience from $5-10$ years and $48 \%$ of them had experience from 16-30 years, This will indicate that they are equipped to obtain training and extension programs to increase and improve the production of frankincense.

\section{Socioeconomic characteristics of sample merchants}

Table 3 shows that, sampled merchants are males who came from Eastern Sudan with an average age of about 48 years; they belong to Bni Amir tribe, $95 \%$ of them were above 40 years and married, level educational of sample merchants was basic school $(95 \%)$, $60 \%$ and $25 \%$ of them have experience from $20-30$ and $31-40$ years respectively. Merchants prefer the workers from Eastern Sudan because they had good experience and very quick in tapping and collection of frankincense. Also Abdalla et al. ${ }^{19}$ showed that the local people got less economic return because the traders and producers are coming from the outside of the area and they have experience for resin production.
Table 2 Socioeconomic characteristics of sampled workers, Blue Nile State $2011 / 2012$

\begin{tabular}{|c|c|}
\hline Item & Percentage \\
\hline Age (years) & 40 \\
\hline $30-40$ & 53 \\
\hline $4 I-50$ & 43 \\
\hline Above 50 & 4 \\
\hline \multicolumn{2}{|l|}{ Marital status: } \\
\hline Married & 51 \\
\hline Un Married & 46 \\
\hline Divorce & 3 \\
\hline \multicolumn{2}{|c|}{ Educational level } \\
\hline Secondary & 3 \\
\hline Basic & 36 \\
\hline Illiterate & 61 \\
\hline \multicolumn{2}{|c|}{ Experience (years) } \\
\hline $5-15$ & 48 \\
\hline $16-30$ & 48 \\
\hline $31-45$ & 4 \\
\hline \multicolumn{2}{|l|}{ Tribe } \\
\hline Bni Amir & 93 \\
\hline Blue Nile tribe & 7 \\
\hline
\end{tabular}

Source: field survey, 2011 
Table 3 Socioeconomic characteristics of sampled merchants, Blue Nile State, $2011 / 2012$

\begin{tabular}{ll}
\hline Item & Percentage \\
\hline Age (years) & 48 \\
$20-30$ & 5 \\
Above 40 & 95 \\
Marital status: & \\
Married & 95 \\
Un Married & 5 \\
Educational level & \\
Secondary & 5 \\
Basic & 95 \\
Experience years & \\
20 - 30 & 60 \\
$31-40$ & 25 \\
Above 4I & 15 \\
\hline
\end{tabular}

Source: field survey, 20II

\section{Net return analysis for frankincense}

According to Table 4 the average cost per metric tons of frankincense was estimated at 1668 SDG (Sudanese Geneah (Sudanese pound)), Percentage of high cost were Government fees and food, which were 43 and 34\% respectively, compared to other costs, However the net return of frankincense was found to be 2332 SDG per metric tons. The net return can be considerably increased if Government fees are decreased. Frankincense was sold locally for 4000 SDG per metric tons in village market, which is low compared to export price which was 15260 SDG per metric tons of non-deductable costs of export (transportation, storage, government fees, ... etc) (US\$ $=2.67 \mathrm{SDG}$, Report of International Monetary Fund.$^{20}$ Percentage of production cost per metric tons to export price (11\%) is low compared to the percentage of production cost per metric tons, to producer price (42\%), Percentage of producer price to export price was (26\%) is also low. Export price is relatively high and provide foreign currency to be used in the country. This sector needs to be supported by Government to improved livelihood of the local communities.

Table 4 Detailed budget of collection of frankincense (SDG/ metric tons), season 20II/2012

\begin{tabular}{llll}
\hline Item & $\begin{array}{l}\text { Average cost of season } \\
\text { for merchant }\end{array}$ & $\begin{array}{l}\text { Average cost per } \\
\text { metric tons SDG }\end{array}$ & $\begin{array}{l}\text { Percentage of } \\
\text { cost }\end{array}$ \\
\hline Workers transport & 6150 & 72 & 4.3 \\
Food & 49200 & 570 & 34 \\
Water & 8085 & 94 & 5.6 \\
Tapping tools & 532.5 & 6 & 0.4 \\
Local containers & 390 & 4.6 & 0.3 \\
Rent of store & 1760 & 20.4 & 1.2 \\
Transport of product & 4260 & 50 & 3 \\
Loading & 5966.5 & 70 & 4.2 \\
Sacks & 5751.5 & 66 & 4 \\
Government fees & 61633.5 & 714 & 43 \\
Total costs & 143629 & 1668 & \\
Production in season (Ton ) & 86.35 & & \\
Price per Ton & 4000 & & \\
\hline
\end{tabular}

Source: field survey, 20II

\section{Conclusion and recommendations}

The study concludes that Frankincense represents a main source of income for merchants and labors in the Blue Nile State. The net return of frankincense collection and marketing to labors was positive (2332SDG/ metric tons). It further concludes that, problems facing workers and merchants are high government fees, water scarcity, limited marketing opportunities, security and finance. It is recommended that these difficulties be addressed for sustainable frankincense system. Bani Amir Tribes one of more skilled tribes work in Boswellia papyrifera, comes from Eastern part of Sudan. Boswellia papyrifera needs efforts to conservation, rehabilitate and adequate sustainable management, which covers large areas in the Blue Nile State. The majority of workers and merchants are from outside the State, whereas the local people are not benefited from frankincense production. For this reason, extension, training and improved equipment are highly required to allow local people to move on in this business to improve their standard of living. State Government should help the local communities to participate in frankincense production through decreasing the taxes and fees imposed locally so as to attract investments on Boswellia papyrifera stands and frankincense production, to realize economical and social return from species.

\section{Acknowledgements}

The authors wish to thanks ustaz, Alfatih, Hammed, Abdulraheem, Administration of Blue Nile State Forest and Dr. Abdelaziz, Abdelfattah Hashim, Agricultural Economic and Policy Research Center. ARC. Sudan. For helped in this study.

\section{Conflict of interest}

Authors declare that there is no conflict of interest. 


\section{References}

1. Gessmalla AF. Regeneration and Resin Yield of Boswellia papyrifera (Del.) Hochst. In the Blue Nile State. Thesis. Sudan Academy of Sciences. 2011.

2. Ogbazghi W. The distribution of Boswellia papyrifera (Del.) Hochst. In Eritrea. Netherlands: Wagningen University; 2001.

3. Adam AA. Some Aspects of Ecology and Management of Boswellia papyrifera (Del) Hochst. In Jebel Marra Area Darfur Sudan. 2003.

4. Gebrehiwot K, Muys B, Haile M, et al. Boswellia papyrifera (Del.) Hochst: a tropical key species in North Ethiopia. Witzenhausen Conference on International Agricultural Research for Development. 2002 .

5. Vollesn K. Burseraceae. In Flora of Ethiopia. I Hedberg, Edwards S, Editors. National Herbariums Addis Ababa University Asmara, Uppsala. $1989 ; 3: 442-478$

6. Salih AA, Yousif E, Khamis MA. Country report for Sudan. In: Review and synthesis on the state of knowledge of Boswellia spp. and commercialization of Frankincense in the dry lands of Eastern Africa. Nairobi; 2002

7. Chikamai BN. Review and synthesis on the state of knowledge of Boswellia species and commercialization of frankincense in the dry lands of Eastern Aafrica. Kenya: Forestry Research Network foe sub- Saharan Africa; 2007.

8. Elamin HM. Trees and shrubs of the Sudan. ISBN. Ithaca Press England. 1990. 484 p.

9. Khan MW. Regeneration of Boswellia papyrifera through branch cuttings, forestry report FAO/Sudan. Sudan: Forestry Research Office; 1977.

10. FAO. Gums, resins and latexes of plant Origin. Non Wood Forest Products series No.6. FAO, Rome. 1995.

11. Michie CA, Cooper E. Frankincense and Myrrh as remedies in children. JR Soc Med. 1991;84(10):602-605.

12. Stiles D. Arid land plants for economic development and desertification control. Desertification Control Bulletin. 1988;17:18-21.

13. McMahon CH. Adventure with frankincense. 2001.

14. FAO. Review and Synthesis on the state of knowledge of Boswellia species and commercialization of frankincense in the dry lands of Eastern Africa. Italy. 2002.

15. Khamis MA. Assessing the potential of Boswellia papyrifera Status for sustainable management in Southern Kordofan state thesis submitted for the requirement of the degree of Direct of philosophy. 2008.

16. BNSI. Blue Nile State Investment map. Ministry of Agriculture of the Blue Nile State. 2004.

17. Sudan Customs Police. Division of Export. 2012

18. Dissertation. University of Khartoum, Sudan.

19. Abdalla AA, Iboniouf MO. Some Socio-Economic Aspects of Boswellia papyrifera and resin production in Blue Nile State-Sudan. J Nat Resour Environ Stu. 2014;2(1)32-38.

20. IMF. International Monetary Fund. Annual Report. 2011. 